Vol. 11 (2002): 121-135.

\title{
Plant communities of field boundaries in Finnish farmland
}

\author{
Sanna Tarmi
}

MTT Agrifood Research Finland, Environmental Management, FIN-31600 Jokioinen, Finland. Current address: Department of Applied Biology, PO Box 27, FIN-00014 University of Helsinki, Finland, e-mail: sanna.tarmi@ helsinki.fi

Hannu Tuuri

MTT Agrifood Research Finland, Data and Information Services, FIN-31600 Jokioinen, Finland

Juha Helenius

Department of Applied Biology, PO Box 27, FIN-00014 University of Helsinki, Finland

To determine the importance of field boundary habitats for farmland biodiversity, we surveyed a total of 193 boundaries from four climatically and agriculturally dissimilar regions in Finland. We measured the current plant species richness and composition of the boundaries, and, based on the differences in vegetation characteristics, we describe six boundary types.

The observed plant species were mainly indicators of fresh to wet soils and moderate to rich mineral nitrogen content. The most frequent species were tall, perennial monocots and dicots indicating the high productivity of the vegetation. Moreover, herbicide-tolerant species were common. No species rare for Finland were found. In animal husbandry regions, the most frequent species were sown grassland species and typical grassland weeds. In cereal production regions, fast-spreading root weeds tolerant of herbicides were the most frequent. Mean species richness was highest in the cluster $\mathrm{Ca}$ lamagrostis-Phalaris (24 species (s) / boundary (b)), which we considered as representative of moist sites with some disturbance by agricultural practices. Most species-poor were the clusters ElymusAnthriscus $(14 \mathrm{~s} / \mathrm{b})$ and Elymus-Cirsium $(16 \mathrm{~s} / \mathrm{b})$, both found predominantly in cereal production regions in southern Finland.

Our results suggest that the biodiversity value of boundaries is lowest in the most intensive cereal production areas and highest in areas of mixed farming.

Key words: plant communities, correspondence analysis, boundaries, diversity, species richness

\section{Introduction}

Intensified agricultural land use has drastically reduced semi-natural habitats. Traditional pastures and a variety of natural meadow types have almost disappeared (Alanen 1997). Moreover, the amount of field boundaries has been considerably reduced (Ruuska and Helenius 1996, Hietala-Koivu 1999). In particular, sub- 
Tarmi, S. et al. Plant communities of field boundaries

surface draining of fields to increase the cultivated area has decreased boundary areas, a common phenomenon in many European countries since the 1950s. In Finland, the area of fields with subsurface drainage increased from $5.1 \%$ (of a total field area of $2292000 \mathrm{ha}$ ) in 1945 (Hilli 1949) to 53\% (2 501000 ha) in 1998 (Information Centre of the Ministry of Agriculture and Forestry 1999). Subsurface drainage is more common in cereal production regions in southern parts of Finland, where up to $91 \%$ of the parcel ditches have been removed during the last four decades (HietalaKoivu 1999). Besides the decrease in the total boundary area, the remaining boundaries have been exposed to herbicide drift from crop spraying and fertiliser misplacement or runoff from cultivated fields, both of which simplify plant community structure and decrease species richness (Marrs et al. 1991, Kleijn and Snoeijing 1997, Hansson and Fogelfors 1998). Higher plant species diversity increases the temporal stability of plant communities (Tilman et al. 1996). More diverse plant communities may also utilise soil mineral nitrogen more efficiently than a species-poor ecosystem (Tilman et al. 1996). Diverse plant communities are important also for heterotrophs exploiting these habitats. Siemann (1998) demonstrated that plant species diversity and productivity increased diversity also at higher trophic levels.

The decreased area and harmful impacts of agricultural practices on remaining boundary habitats have been a common phenomena in Western Europe during the last century. Despite this, the importance of these habitats for wildlife of the agricultural environment has been shown in many studies. Boundaries enhance arthropod diversity, including the natural enemies of crop pests (Dennis and Fry 1992, Canters and Tamis 1999, Pfiffner and Luka 2000). They increase overall carabid densities (Fournier and Loreau 1999) in cultivated areas and provide overwintering habitats for e.g. spiders (Bayram and Luff 1993). Flowering plants are a food resource for pollinators (Lagerlöf et al. 1992,
Bäckman and Tiainen 2002). Field boundaries also provide important links among favourable habitat patches for butterfly species (Dover et al. 1992, Sparks and Parish 1995), and the various boundary types support a diverse butterfly fauna (Saarinen et al. 1998). Boundaries provide important feeding and nesting habitats for gamebirds (e.g. Aebischer et al. 1994, Tiainen and Pakkala 2000). As a consequence of intensified land use, the decline in numbers of grey partridge, as well as several other farmland bird species, has been reported in Finland (Väisänen 1999).

In this research, we tried to estimate the biodiversity value of Finnish field boundaries by surveying plant assemblages. Our specific objectives were: 1) to describe plant species diversity and composition in Finnish field boundaries, 2) to identify boundary plant communities based on species composition, and 3) to describe the factors determining these types on the basis of the ecological requirements of the plant species. In addition, our objective was to estimate the value of boundary plant communities as secondary habitats for meadow plant species. The importance of current boundary plant communities for animals is also discussed.

We know only one earlier study on Finnish field boundary vegetation, which focused on the species' value as silage for cattle, rather than on the biodiversity aspect (Hilli 1949).

This study was made just before management measures of the 1st Finnish agri-environmental scheme required by EU regulations were applied. One target of the agri-environmental scheme is to maintain biodiversity and landscape in agricultural environment. In the basic scheme, management agreement includes the widening of boundaries along waterways to one (main ditches) or three (stream, river, lake) meters wide. Boundaries should not be fertilized or treated with pesticides. Mowing is mentioned as a useful management for wildlife, but it is not obligatory treatment (Ministry of Agriculture and Forestry 2000). 


\section{AGRICULTURAL AND FOOD SCIENCE IN FINLAND}

Vol. 11 (2002): 121-135.

\section{Material and methods}

Botanical studies of field boundaries were included in a broad nationwide MYTVAS -project on Monitoring the Impacts of the Agri-Environmental Support Scheme in 1995-1999. This project was carried out in four watershed regions, which are representative of agricultural regions in Finland. Lepsämänjoki, about $30 \mathrm{~km} \mathrm{~N}$ of Helsinki, and Yläneenjoki, about $50 \mathrm{~km} \mathrm{NE}$ of Turku, are predominantly cereal production regions. Lestijoki, about $60 \mathrm{~km} \mathrm{SE}$ of Kokkola, is a region of animal husbandry and mixed farming, and Taipaleenjoki, about $20 \mathrm{~km} \mathrm{~W}$ of Joensuu, is a typical animal husbandry region of small farms and fine-grained landscape structure. The co-ordinates of the regions are Lepsämänjoki $60^{\circ} 20^{\prime} \mathrm{N}, 60^{\circ} 27^{\prime} \mathrm{N}, 24^{\circ} 37^{\prime} \mathrm{E}, 2^{\circ} 49^{\prime}$ E, Yläneenjoki $60^{\circ} 47^{\prime} \mathrm{N}$ to $60^{\circ} 56^{\prime} \mathrm{N}$ and $22^{\circ} 25^{\prime} \mathrm{E}$ to $22^{\circ} 40^{\prime}$

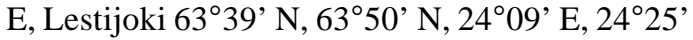
E and Taipaleenjoki $62^{\circ} 36^{\prime} \mathrm{N}, 62^{\circ} 38^{\prime} \mathrm{N}, 29^{\circ} 10^{\prime}$ E, $29^{\circ} 20^{\prime} \mathrm{E}$.

The most common soil types in Lepsämänjoki are sandy clay (in 55\% of the boundaries), fine sand (26\%), and clay (16\%); in Yläneenjoki fine sand $(61 \%)$ and sandy clay $(31 \%)$; in Lestijoki fine sand (91\%), and in Taipaleenjoki fine sand (59\%), mull (19\%) and silt (13\%) (Tarmi and Helenius, unpublished data). The average thermal growing season in Yläneenjoki and Lepsämänjoki is 170 days, in Taipaleenjoki 155 days, and in Lestijoki 150 days (Alalammi 1987). Average annual precipitation is 582, 619,612 and $544 \mathrm{~mm}$, respectively.

Our fieldwork period was from the beginning of July to mid-August 1995. To facilitate site selection in the field, we made a preliminary choice of boundaries from aerial photographs (scale 1:20000). Subsequently we refined the choice using the following criteria. (1) Location next to a waterway such as a main ditch, river or lake. (2) No or only a few trees and shrubs present (because these might affect the species composition in the herbaceous layer). (3) No forest edge next to a site because of the possible shading effects and the dispersal of forest field layer species. Only sites matching these criteria were included.

We studied 193 boundaries in all (50 in Yläneenjoki, 52 in Lepsämänjoki, 58 in Lestijoki and 33 in Taipaleenjoki). The boundary was determined as a zone from a field edge to the beginning of a slope. All plant species were measured in one to five $0.25 \mathrm{~m}^{2}$ quadrates $(0.5$ $\mathrm{m} \times 0.5 \mathrm{~m}$ ) in each boundary (Fig. 1). The distance of a quadrate to the field was measured as the distance from the field edge to the nearest, parallel side of the quadrate. We aimed at a quadrate distance of $50 \mathrm{~cm}$ from the field edge, but in practice these varied from zero to over two metres depending on the variation in boundary widths. When the boundary width was less than $50 \mathrm{~cm}$, less than five quadrates were studied. When the boundary width was less than one metre, quadrate distance from the field was less than aimed $50 \mathrm{~cm}$. In cases of over one metre the distance from the field was more than $50 \mathrm{~cm}$. The width of a boundary was measured in all five quadrate sites to calculate the mean width based on five values. The minimum distance of the first sample quadrate from one end of a boundary was 10 metres and the distance between quadrates 20 metres.

We used Oksanen's nine class scale (1981), $1-\leq 0.8 \%, 2-\leq 1.6 \%, 3-\leq 3.1 \%, 4-\leq 6.3 \%, 5$ $-\leq 12.5 \%, 6-\leq 25 \%, 7-\leq 50 \%, 8-\leq 75 \%, 9-$ $\leq 100 \%$, in estimating plant species' coverage. Because our field work schedule was tight, field workers identified sterile or difficult grasses only to genus level. In species nomenclature, we follow Hämet-Ahti et al. (1986). To describe the ecological characters of the species, we applied Ellenberg et al. (1991) indicator values.

In the original data, we determined the cover values of the species in each $0.25 \mathrm{~m}^{2}$ sample quadrate using a nine-class scale. For the statistical analyses, we combined the quadrate data to calculate the mean cover of each species in a boundary. Boundaries with only two quadrates were made passive in the correspondence analysis (CA), but were included in classification. Species which were present only in one boundary were dropped from the CA (listed in App. 1) 


\section{AGRICULTURAL AND FOOD SCIENCE IN FINLAND}

Tarmi, S. et al. Plant communities of field boundaries

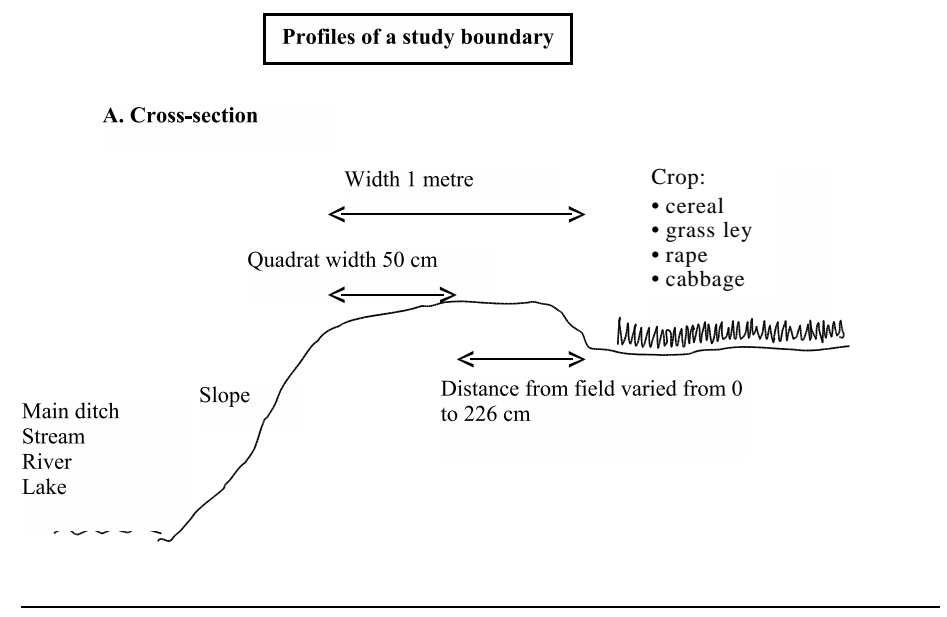

Fig. 1. Profiles of a study boundary. The optimal location for sample quadrates was $50 \mathrm{~cm}$ from field edge. See Tables 2 and 5 for the variation of boundary widths and distances of quadrates from fields.

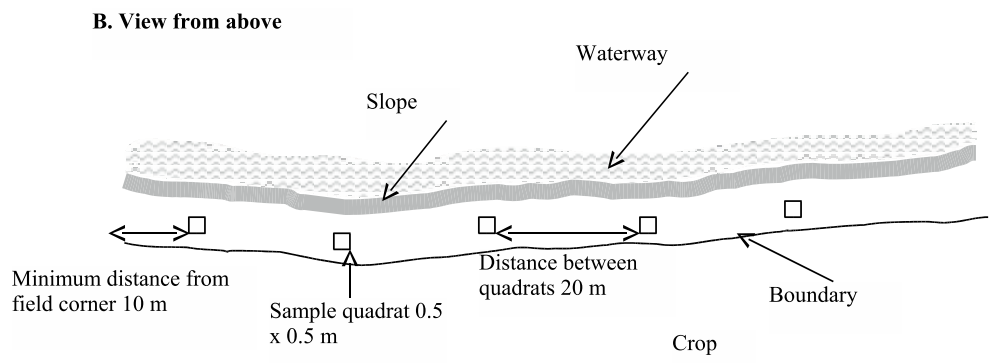

and those present only in two or three boundaThe classes for each species were replaced with ries were unweighted, because in some applications individual samples with species of low frequency may distort the analysis (Hill 1979). the corresponding class centres by calculating the geometric means of lower and upper limits of cover percentages. The first cover class,

The quadrate data transformation was as follows: Cover class 9 was merged with class 8 . $>0-0.8 \%$, was replaced by the arithmetic mean of the lower and the upper limits, as 0 does not

Table 1. Number of boundaries/areas, their division into clusters, and the mean width (cm) of boundaries/clusters.

\begin{tabular}{ccrrrrrrrr}
\hline Cluster & LEPSA & YLÄNE & TAIPA & LESTI & Total & Mean width & SE & Min & Max \\
\hline 1 & 1 & 0 & 4 & 40 & 45 & 139 & 23.9 & 6 & 780 \\
2 & 1 & 1 & 8 & 8 & 18 & 82 & 13.1 & 12 & 276 \\
3 & 0 & 0 & 11 & 1 & 12 & 109 & 18.4 & 18 & 204 \\
4 & 1 & 0 & 1 & 3 & 5 & 78 & 11.8 & 40 & 100 \\
5 & 22 & 37 & 4 & 1 & 64 & 86 & 13.9 & 4 & 860 \\
6 & 13 & 4 & 1 & 5 & 23 & 130 & 30.1 & 13 & 660 \\
7 & 14 & 8 & 1 & 0 & 26 & 63 & 5.1 & 28 & 108 \\
Total & 52 & 50 & 33 & 58 & 193 & & & & \\
\hline
\end{tabular}

$\mathrm{SE}=$ standard error of the mean 
allow computing a geometric mean. A mean cover percentage per species was then obtained as an arithmetic mean of the quadrates. Finally, these cover percentages were replaced with the corresponding value from the original scale (classes from 1 to 8 ). These new values approximate the cover percentages of species (Oksanen 1981).

We used ordination technique to reveal the major variation in the species abundance data of boundaries. CA was performed with the program Canoco $^{\text {TM }}$ (ter Braak 1987). By CA it may be possible to detect whether unknown environmental variables determine the species occurrences in the data set (Jongman et al. 1995). The ordination diagram presented the similarity or dissimilarity of the species compositions of the test boundaries. Based on the scores of the first four axes of ordination, the boundaries were grouped into clusters by Ward's method (see Jongman et al. 1995). Cluster analysis was performed using the SASTM Statistical package's CLUSTER and TREE procedures.

The mean species richness was measured for each cluster using only boundaries with an equal sample size of five quadrate samples to allow for the asymptotic dependence of the species number on the sample size. Because clustering is a subjective method, i.e. one may decide the number of groups to be left after fusion, we found it inappropriate to make any statistical test for species richness between clusters. However, we found it important to check whether the distance from the field could, at least partially, be one of the factors affecting the species richness in these data. To test the effect of distance from the field edge on plant species richness, we divided boundaries into three classes: 1) the mean distance of the quadrates from field edge $0-19 \mathrm{~cm}$ $(\mathrm{n}=60), 2)$ distance $20-39 \mathrm{~cm}(\mathrm{n}=36)$, and 3$)$ distance $\geq 40 \mathrm{~cm}(\mathrm{n}=50)$. To test the differences between classes we used ANOVA, which was performed with SYSTAT ${ }^{\mathrm{TM}}$ (SPSS ${ }^{\mathrm{TM}}$ Inc. 1997). The normality of variables in ANOVA was checked from the normal probability plots of residuals. The homogeneity of variables was tested with Cochran's test.

\section{Results}

The results of the CA ordination indicated dissimilarities in boundary vegetation between the regions. The studied regions formed three groups of plots in the first two axes in CA ordination (Fig. 2). Southern regions were plotted as one cloud of plots, whereas Lestijoki and Taipaleenjoki formed their own groups, from which Taipaleenjoki sites were plotted in a more scattered way. Points in the first two groups were arranged in relation to the first axis, while the Taipaleenjoki sites were scattered in relation to the second axis (Fig. 2).

Based on the scores of the first four axes of ordination, we classified the boundaries by using Ward's clustering method. We found seven clusters to represent a reasonable level of ag-

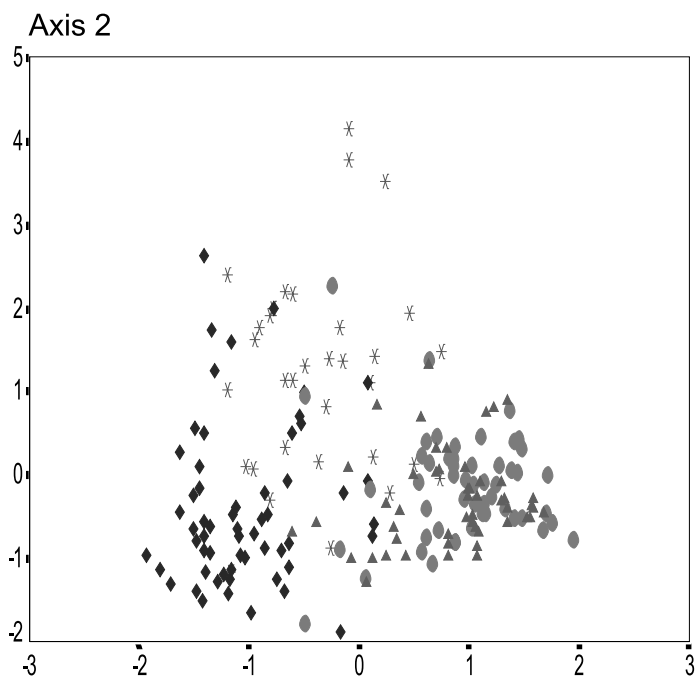

Axis 1

\section{Area: $\star$ Taipaleenjoki • Lestijoki • Lepsämänjoki $\triangle$ Yläneenjoki}

Fig. 2. Ordination diagram of correspondence analysis of the studied field boundaries based on their plant species composition. Different symbols represent the four study areas. For axis 1 eigenvalue $=0.424$, percentage variance of species data 10.6, and for axis 2 eigenvalue $=0.224$, percentage variance of species data 5.6. 
Tarmi, S. et al. Plant communities of field boundaries

glomeration even though cluster 4 (C4) included only five boundaries at this level (Table 1, Fig. 3). Boundaries in $\mathrm{C} 4$ were interpreted as outliers and were not considered as representative boundary group. In the next level of fusion $\mathrm{C} 4$ would have been merged with cluster 2 (C2). As in CA results, groups that were formed by clustering also indicated that some local environmental factors may determine the vegetation composition of boundaries. Cluster 1 (C1) included mainly Lestijoki sites and cluster 3 (C3) mainly Taipaleenjoki sites (Fig. 3, Table 1). Cluster 2 (C2) represents mainly sites from Taipaleenjoki and Lestijoki whereas clusters 5 (C5) and 7 (C7) represent mainly sites from Lepsämänjoki and Yläneenjoki. Cluster 6 (C6) is the most independent of any particular region and includes several sites from southern regions and Lestijoki.

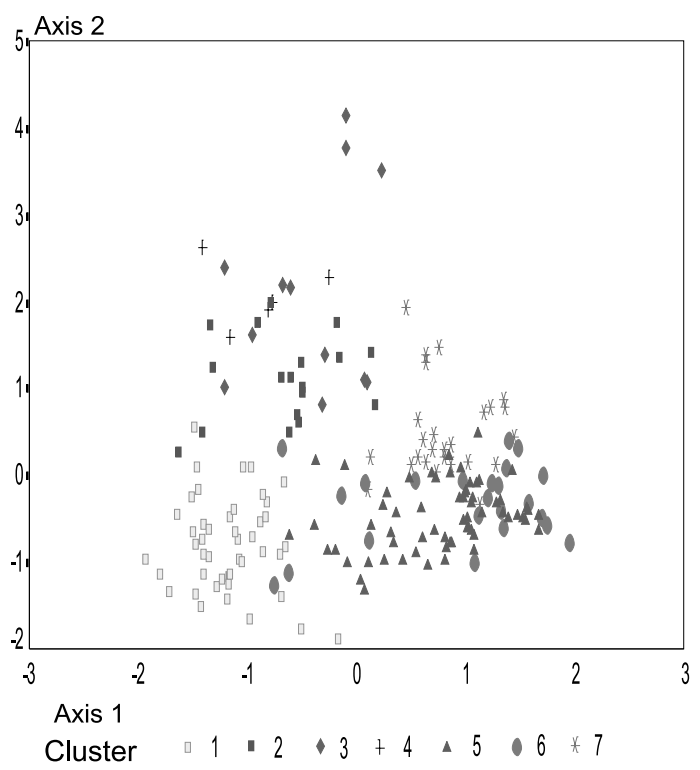

Fig. 3. Ordination diagram of correspondence analysis. Each plot represents one field boundary. Based on their species composition, boundaries are grouped into seven clusters from a cluster analysis (Ward's method). For axis 1 eigenvalue $=0.424$, percentage variance of species data 10.6, and for axis 2 eigenvalue $=0.224$, percentage variance of species data 5.6. Each symbol represents one cluster.
Each cluster was described as a group of boundaries that had the most similar plant species compositions (Figs. 3 and 4). Because we have mainly genus data on monocot (grassy) species, we use the preliminary results of later studies in these regions to introduce the exact species. Unidentified species belonged most often to the genera Poa, Festuca, Agrostis, $\mathrm{Ca}$ lamagrostis and Carex (App. 1). According to the later studies on these regions (Tarmi and Helenius, unpublished results from 1997-1999), Poa turned out to be mostly P. pratensis, Festuca F. pratensis or F. rubra ${ }_{2}$ and Agrostis A. capillaris, A. gigantea or A. stolonifera. Calamagrostis was most often $C$. canescens, $C$. arundinacea, C. epigejos or C. purpurea. Carex was identified as $C$. acuta, $C$. canescens, C. nigra, C. ovalis or C. vesicaria species.

Each cluster was named by the characteristic species (Table 2) and were described as follows:

C1 - Ranunculus-Phleum: Grasses such as $P h$ leum pratense, Poa sp., Agrostis sp., and Festuca sp. were common. The perennial herbs Ranunculus repens, Rumex acetosa, Trifolium repens, Achillea millefolium, and Leontodon autumnalis were abundant. Annual species were rarely found.

C2 - Filipendula-Ranunculus: In this cluster, none of the species attained absolute dominance compared to each other, but many species occurred with moderate frequency. It was characterised by tall herbs favouring moist sites such as Filipendula ulmaria, Angelica sylvestris, Cirsium helenioides and Calamagrostis sp.. Moreover, species of nutrient rich sites such as Urtica dioica, Epilobium angustifolium and Galeopsis sp. were common.

C3 - Calamagrostis-Phalaris: Tall grasses $\mathrm{Ca}$ lamagrostis sp. and Phalaris arundinacea were characteristic of the cluster. Perennial species indicating moist or wet sites - Carex sp., Achillea ptarmica, Angelica sylvestris, Lysimachia sp., Polygonum amhibium, Peucedanum palustre, Lactuca sibirica - were 
Vol. 11 (2002): 121-135.

Fig. 4. Ordination diagram of correspondence analysis. Plotted are the most frequently occurring species, with each plot representing one species. For axis 1 eigenvalue $=0.424$, percentage variance of species data 10.6 , and for axis 2 eigenvalue $=0.224$, percentage variance of species data 5.6.

Species abbreviations: ACH MIL Achillea millefolium, ACH PTA A. ptarmica, AEG POD Aegopodium podagraria, AGR SP Agrostis sp., LYS SP Lysimachia sp., ALC SP Alchemilla sp., ALO PRA Alopecurus pratensis, ANG SYL Angelica sylvestris, ANT SYL Anthriscus sylvestris, ART VUL Artemisia vulgaris, CAL SP Calamagrostis sp., CAR SP Carex sp., CER FON Cerastium fontanum, CHE ALB Chenopodium album, CIR ARV Cirsium arvense, CIR HEL C. helenioides, DES

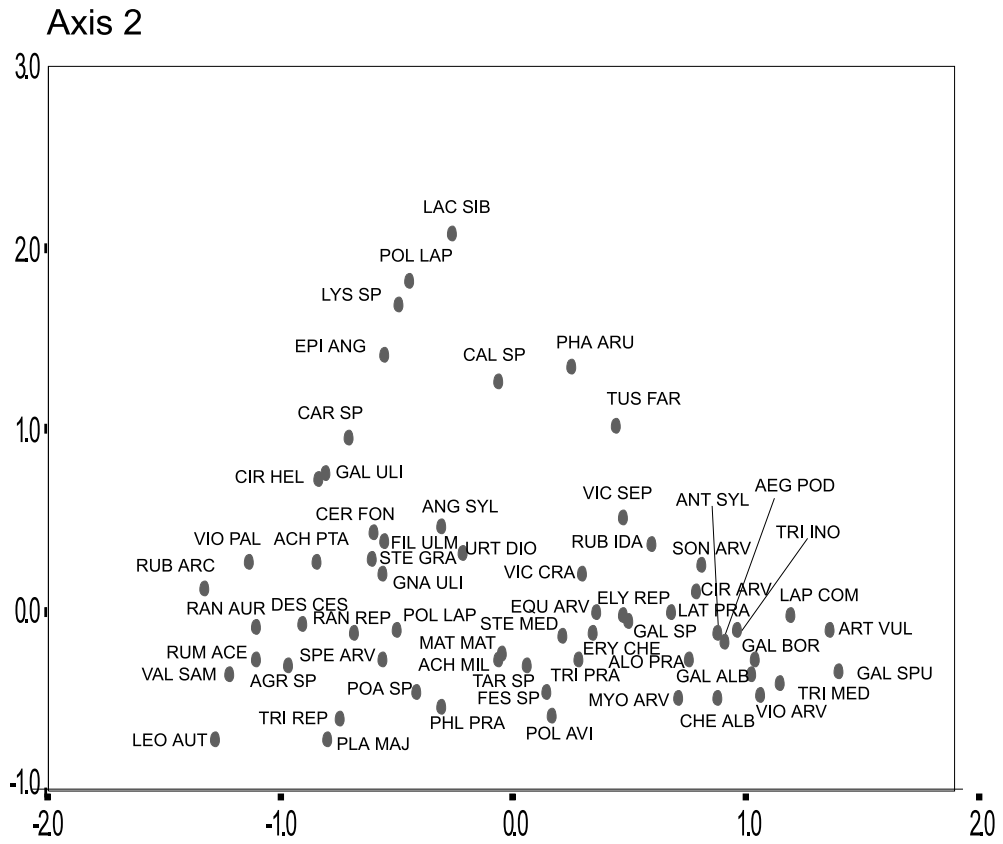

Axis 1

CES Deschampsia cespitosa, ELY REP Elymus repens, EPI ANG Epilobium angustifolium, ERY CHE Erysimum cheiranthoides, EQU ARV Equisetum arvense, FES SP Festuca sp., FIL ULM Filipendula ulmaria, GAL SP Galeopsis sp., GAL ALB Galium album, GAL BOR G. boreale, GAL SPU G. spurium, GAL ULI G. uliginosum, GNA ULI Gnaphalium uliginosum, LAC SIB Lactuca sibirica, LAP COM Lapsana communis, LAT PRA Lathyrus pratensis, LEO AUT Leontodon autumnalis, MAT MAT Matricaria matricarioides, MYO ARV Myosotis arvensis, PHA ARU Phalaris arundinacea, PHL PRA Phleum pratense, PLA MAJ Plantago major, POA SP Poa sp., POL AMP Polygonum amphibium, POL AVI $P$. aviculare, POL LAP P. lapathifolium, RAN ACR Ranunculus acris, RAN REP R. repens, RUB ARC Rubus arcticus, RUB IDA $R$. idaeus, RUM ACE Rumex acetosa, SON ARV Sonchus arvensis, SPE ARV Spergula arvensis, STE GRA Stellaria graminea, STE MED $S$. media, TAR SP Taraxacum sp., TRI MED T. medium, TRI PRA T. pratense, TRI REP T. repens, TRI INO Tripleurospermum inodorum, TUS FAR Tussilago farfara, URT DIO Urtica dioica, VAL SAM Valeriana sambucifolia, VIC CRA Vicia cracca, VIC SEP V. sepium, VIO ARV Viola arvensis, VIO PAL V. palustris.

frequent, as well as some annuals such as Polygonum hydropiper, Stellaria media and Galium uliginosum.

C4 - Epilobium-Urtica: Most frequent species were Elymus repens, Epilobium angustifolium and Urtica dioica.

C5 - Elymus-Anthriscus: Elymus repens was a highly dominant species. Other frequent species were mostly grasses, such as Phleum pratense, Poa sp., Alopecurus pratensis and ruderal herbs like Cirsium arvense, Anthriscus sylvestris. A characteristic species for only this cluster, even if not very frequent, was Aegopodium podagraria.

C6 - Elymus-Tripleurospermum: Elymus repens and Alopecurus pratensis were the most frequent grasses. Annual herbs such as Galeopsis sp., Stellaria media, Tripleurospermum inodorum, and Polygonum aviculare were characteristic of this cluster.

C7 - Elymus-Cirsium: The most frequent species were Elymus repens, Calamagrostis sp., Cirsium arvense, Equisetum arvense, Lathyrus pratensis, Tussilago farfara, Vicia cracca and Achillea millefolium. 
Tarmi, S. et al. Plant communities of field boundaries

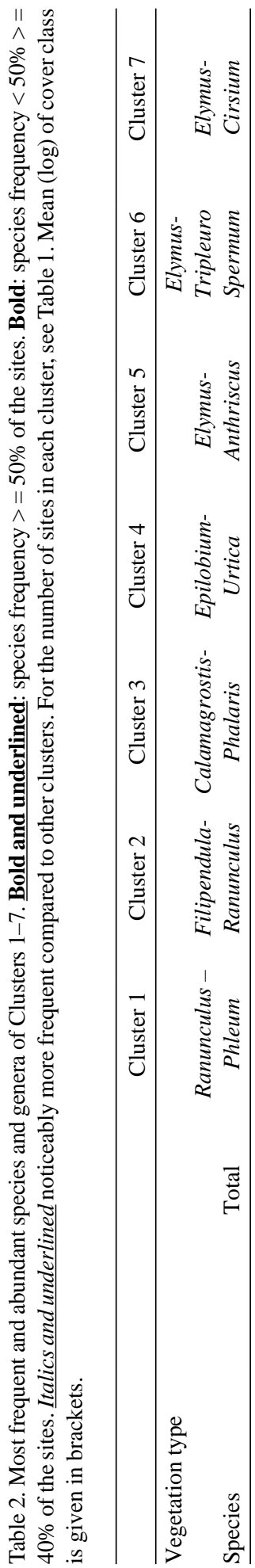

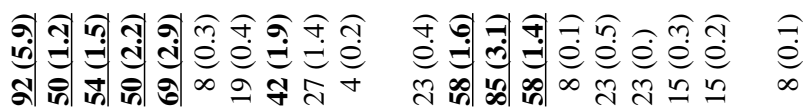

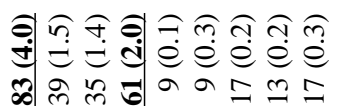

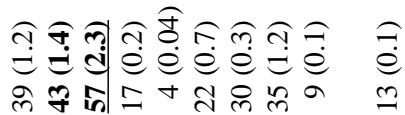

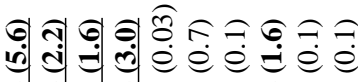

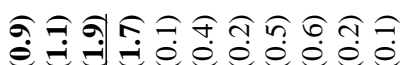

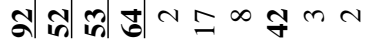

$\neg$ ᄀ

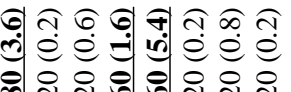

$\stackrel{0}{+} \stackrel{0}{0} \stackrel{0}{0}$

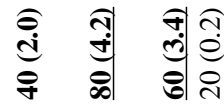

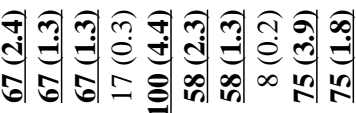

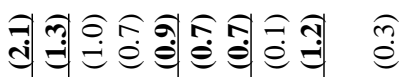

ㅅำ

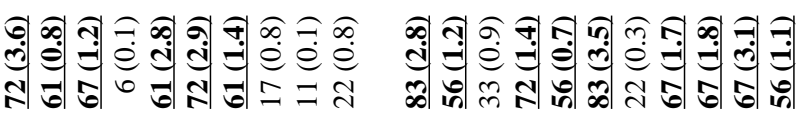

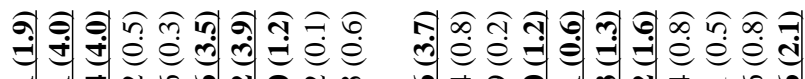

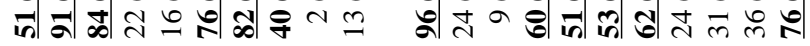

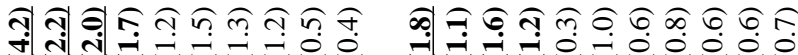

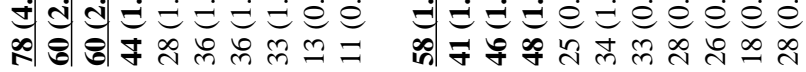

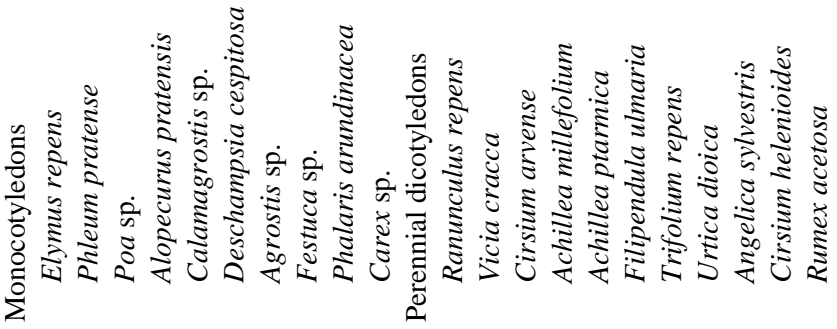


Vol. 11 (2002): 121-135.

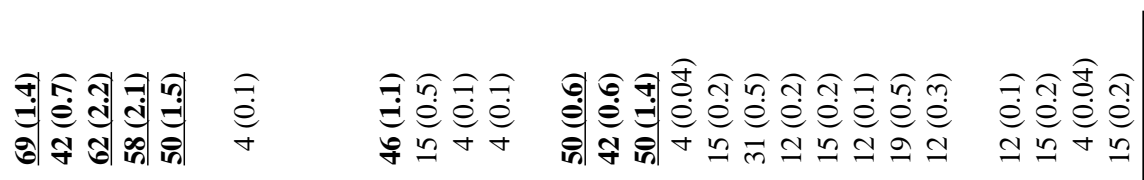

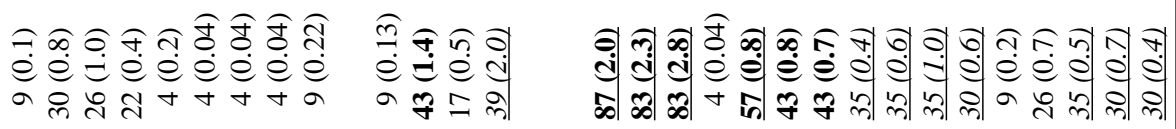

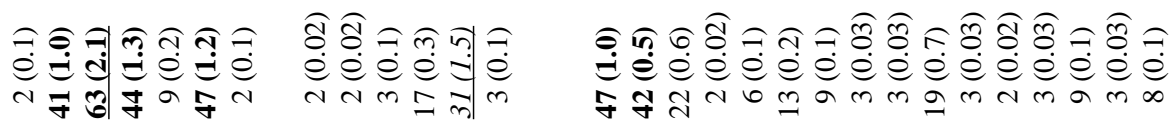

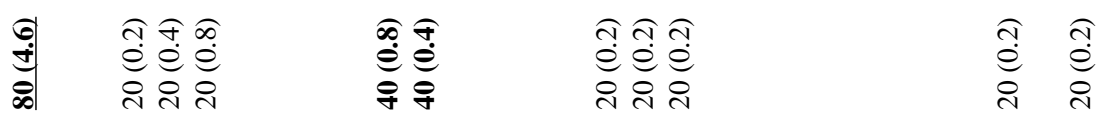

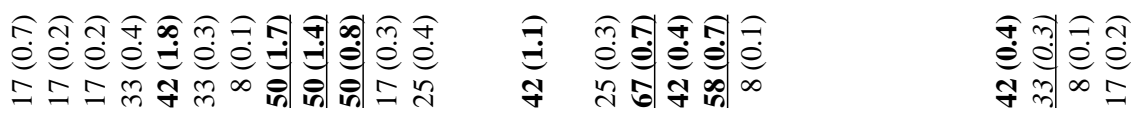

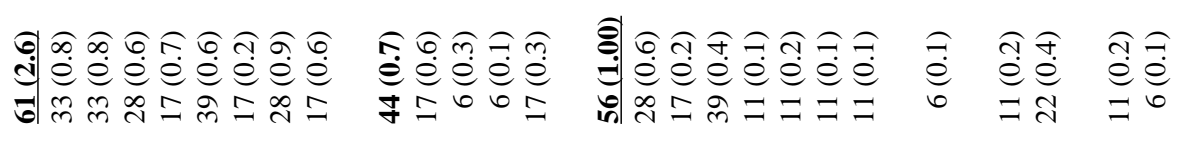

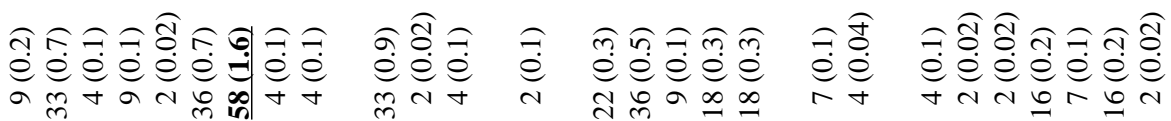

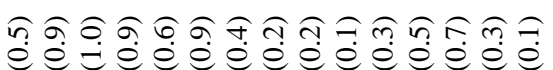

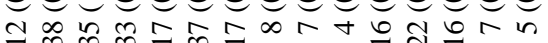

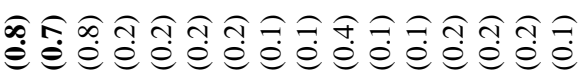
f

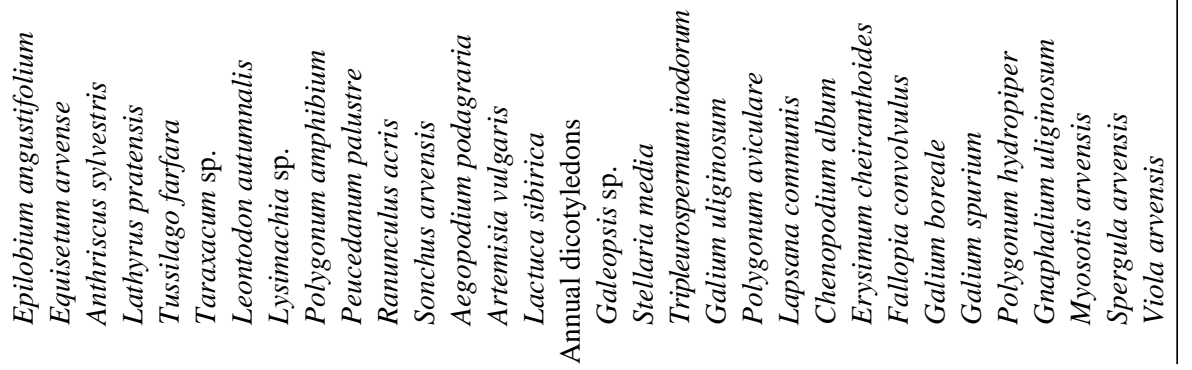


Tarmi, S. et al. Plant communities of field boundaries

Table 3. Plant species richness per $1.25 \mathrm{~m}^{2}$ (five $0.25 \mathrm{~m}^{2}$ quadrates) and distance $(\mathrm{cm}$ ) of quadrates from the field edge in each cluster.

\begin{tabular}{crcrrrrrrr}
\hline & \multicolumn{3}{c}{$\begin{array}{c}\text { Species } \\
\text { richness }\end{array}$} & \multicolumn{9}{c}{$\begin{array}{c}\text { Distance } \\
\text { from field }\end{array}$} \\
\hline Cluster & N & Mean & SE & Min & Max & Mean & SE & Min & Max \\
\hline 1 & 37 & 19 & 5.4 & 6 & 28 & 28 & 2.9 & 0 & 50 \\
2 & 12 & 20 & 8.2 & 10 & 35 & 40 & 17.4 & 0 & 226 \\
3 & 9 & 24 & 8.3 & 12 & 36 & 38 & 5.7 & 0 & 50 \\
4 & 3 & 13 & 3.6 & 8 & 15 & 43 & 1.8 & 40 & 46 \\
5 & 48 & 14 & 5.1 & 2 & 24 & 21 & 3.2 & 0 & 80 \\
6 & 19 & 19 & 5.6 & 11 & 35 & 29 & 6.1 & 0 & 89 \\
7 & 19 & 16 & 5.6 & 7 & 23 & 19 & 3.9 & 0 & 50 \\
\hline
\end{tabular}

$\mathrm{N}=$ number of boundaries, $\mathrm{SE}=$ standard error of the mean

The mean species richness was highest in the Calamagrostis-Phalaris type (Table 3) whereas Elymus-Anthriscus and Elymus-Cirsi$u m$ types were the most species-poor among all types. When the effect of distance from the field on species richness was tested, no statistically significant differences between the three classes (ANOVA, $\mathrm{df}=2, \mathrm{f}=1.23, \mathrm{P}=0.29$ ) was found. The mean species richness next to field edges with crops was $16.12 \pm 0.87($ mean \pm SE), at $20-39 \mathrm{~cm}$ distance from the field edge 17.14 \pm 1.12 , and at $40 \mathrm{~cm}$ or more from the edge $18.14 \pm 0.95$.

The mean widths of the boundaries were highest in C1 and in C6 (Table 1). The narrowest boundaries, slightly over half metre in width, were in C7. The total number of plant species identified in the boundaries was 140 . This number does not include plants identified only to genus level, except the Taraxacum genus.

After the data modifications that preceded statistical analyses, 100 identified species were included in CA and cluster analysis. The ecological requirements of these species were described based on Ellenberg et al. (1991) classification. However, some species' ecological requirements are not fully understood, so that the occurrence of 87 species in relation to soil moisture and 80 species in relation to soil nitrogen were included for further description.

In this study, none of the examined species indicated dry soil conditions, but $12 \%$ of the species indicated soil conditions between dry and fresh. More than half of the species $(52 \%)$ indicated moderately fresh conditions, $25 \%$ indicated moist or nearly wet soils, and $11 \%$ indicated wet soils. For mineral nitrogen, $17 \%$ of the species indicated poor soils and the largest group, $45 \%$ of the species, indicated intermediate soils. Nitrogen-rich soils were indicated by $17 \%$ of species and $16 \%$ (13 species) were nitrogen indicators.

\section{Discussion}

Plant species observed during the survey were mainly species indicating fresh to wet soil moisture conditions and moderate to rich mineral nitrogen content in the soil. The most frequent species were tall, perennial monocots and dicots indicating high productivity in the boundaries. Moreover, many of the observed species are known to tolerate herbicides, which has probably enhanced their abundance in boundaries exposed to herbicide drift from crop sprayings, or from direct sprayings that were permitted until 1994. As with the results of Kleijn et al. (1998) study of boundaries elsewhere in Europe, we observed no rare plant species. Species listed by 
Vol. 11 (2002): 121-135.

Hilli (1949) as the most abundant were similar to those in our study except Leucanthemum vulgare. It used to be a common grassland weed species, but has declined due to gradual changes in cultivation methods (Raatikainen 1991). In this study it was found only once.

Lestijoki and Taipaleenjoki are dairy production regions (Granlund et al. 2000) and more than half of the cultivated area in the crop rotation is grassland (Grönroos et al. 1998) for grazing and silage. These are not ploughed annually but at intervals of three to five years. Compared to cereal production herbicides are rarely used. According to our field observations, especially on the pastures, grassland fields often reach in to the boundary area or, on gently sloping riverbanks, even to the shoreline. This means that the border between the original boundary and cultivated grassland is unclear, or in extreme situations there is no original boundary but only ley grassland. Boundaries highly similar in species to ley grassland were mainly grouped into the $\mathrm{C} 1$, Ranunculus-Phleum type, even if their relative abundance of species was different. The most commonly cultivated species such as $P h$ leum pratense and Festuca pratensis as well as many species that are considered typical grassland weeds in leys, were frequent. Especially $L e$ ontodon autumnalis is common in boundaries and in old leys, where the coverage of sown grasses has decreased (Raatikainen 1991). For C2, the Calamagrostis Phalaris type, several species favouring nitrogen and moist soils were characteristic. Of the boundaries studied, C2 represents probably the most fertile sites. In $\mathrm{C} 2$ the dominant species indicate moist or wet soil conditions. Moisture conditions may explain the high species richness in this group. These boundaries were probably left in a natural state and were not affected by cultivation practices, as the species composition would indicate. This is because seasonally wet habitats are impossible or not profitable to cultivate. Thereby these boundaries seem to belong to the least disturbed habitat type among the groups. Lactuca sibirica, typically a species of river and stream shores in $\mathrm{E}$ and $\mathrm{N}$ Finland, is more frequent in this than in the other clusters. C2 and C3 have the highest species diversity of all the groups. This may be partly explained by crop rotation, which is common in the Lestijoki and Taipaleenjoki regions. Crop rotation has been shown to be an important factor for boundary species composition (Kleijn and Verbeek 2000). In Taipaleenjoki, the landscape is also more fine-grained, and agriculture is less intensive than in the other regions, which may have contributed to the higher species richness in $\mathrm{C} 2$, the Calamagrostis-Phalaris group.

Clusters C5, Elymus-Anthriscus, C6, ElymusTripleurospermum, and C7 Elymus-Cirsium, represent southern regions. There more than half the field area is under spring cereal production yearly, which means ploughing, tilling and the use of herbicides are annual practices. In these fairly similar clusters, species tolerant of herbicides and/or capable of spreading fast by rhizomes or seeds to bare soil gaps were the most common. Elymus repens and Cirsium arvense were frequent everywhere, most of all in C7. These most frequent species indicate fresh soil moisture conditions. Of all six representative clusters $\mathrm{C} 5$ was the poorest in species. Only a few species, mainly ruderals, constituted the main part of the vegetation in C5. However, the mean number of species was clearly higher even in this species poor group compared with a study on Dutch boundaries (Kleijn 1997). Even though the sampling areas in the Dutch study were larger than ours $\left(4 \mathrm{~m}^{2}\right)$, the highest mean number of species among groups was 11.8. Aegopodium podagraria was the characteristic species of C5. It is native to southern Finland and easily invades new sites using rhizomes. C7 is close to $\mathrm{C} 5$, but the higher numbers of frequently encountered species indicate a slightly more heterogeneous vegetation structure. However, the frequency and abundance of Elymus repens was very high in both groups. C6 differs from others by the frequent occurrences of annual species, which is indicative of recent disturbance destroying permanent vegetation cover. This was probably caused by recent mechanical disturbance during cultivation. Also, heavy rains in summer 1995, just be- 
Tarmi, S. et al. Plant communities of field boundaries

fore our fieldwork started, may have caused soil disturbance. In several boundaries we observed gaps caused by erosion without permanent vegetation cover. Exceptional weather conditions may have enhanced the amount of annuals in 1995 compared to more typical summers. This suggests that temporal aspects such as the stage of vegetation succession, should also be considered in boundary classification.

According to this study, the sample quadrate distance from the field was not a significant factor for species richness. However, boundary width has been shown to be significant for overall species diversity in boundary habitats (Ma et al. 2002). Cultivation practices affect boundary vegetation with different intensity depending on the distance from the field. As a result, variable vegetation zones have developed in the boundary, which increases species diversity in the whole boundary community (Ma et al. 2002).

On the basis of our study, the effects of farming practices on species composition seem obvious. However, also indirect factors should be considered. The current division between crop and dairy production along Finland's north-south gradient is partly a consequence of the country's climatic conditions, which allows profitable crop production only in southern parts of Finland. Another explanatory factor is the agricultural policy of the 70s, which also supported this regional specialisation of farms into crop or dairy production. In the past few years an increase in organic production has favoured mixed farming also in the south because of the need for animal manure for organic crop production. Mixed farming could enhance the diversity of boundary types at farm level, which was reported as being important in e.g. providing food for granivorous birds (Wilson et al. 1999).

In our results, many of the boundaries were species-poor and dominated by grasses. At a boundary level they have low diversity value but at a landscape level they may increase the interboundary diversity among boundaries with dissimilar species compositions (Le Coeur et al. 1997). Tussocks forming grasses are important overwintering sites for spiders and ground bee- tles, some of them being also beneficial to pest predators (Bayram and Luff 1993, Dennis et al. 1994). Among grasses of this growth form Agrostis and Poa species and Deschampsia cespitosa were common in the studied boundaries. We did not measure the flowering intensity of plants, which prevents us from estimating the exact importance of species as sources of nectar. However, it is known that many frequently found species such as Cirsium arvense and Epilobium angustifolium are important nectar flowers for butterflies (Kuussaari et al. 2001) and for bumblebees (Bäckman and Tiainen 2002). Moreover, such species as Urtica dioica, Festuca sp. and Poa sp. are important host plants for butterfly larvae (Silfverberg 1996).

Many common weed species were observed frequently in the boundaries and farmers often regard boundaries as a source of weeds and thus basically harmful. However, weeds have been reported as spreading only short distances into a field (Marshall 1989, Marshall and Arnold 1995, Wilson and Aebischer 1995). When weeds, especially fast spreading clonal weeds such as Elymus repens and Cirsium arvense, dominate the boundary community, management is needed to diminish their abundance. Cutting and removing should thus be applied in order to reduce not only weeds but also nutrient and litter accumulation in boundaries. If nutrients are not diminished by biomass removal, boundaries buffer nutrient leaching to surface waters for only a short time. Moreover, increased mineral nitrogen results in higher productivity and litter accumulation, which may decrease the species diversity by preventing seedlings from becoming established (Foster and Gross 1998). Kleijn (1996) also stressed the importance of cutting and removing to avoid nutrient accumulation, because boundary species are able to capture nutrients from a field. If weeds are a serious problem in a boundary, re-establishment by sowing could be an option. Biodiversity values remains low if only grassy species are sown. However, species such as Dactylis glomerata have been demonstrated to be effective in suppressing invasions of Elymus repens (Marshall 1990). 
Vol. 11 (2002): 121-135.

Ideally local seed mixtures of wild plants could be used to enhance species richness, but this may be difficult in practice. Sown species may be too sensitive to herbicides, so that one accidental herbicide drift may destroy the vegetation. Such species may also not have the ability to survive in nutrient rich, disturbed habitats such as boundaries most often are.

Agricultural practices are important for determining plant communities in boundaries. These habitats are exposed to herbicides, fertilisers, ploughing, and sometimes even used as grassland. The intensity of different disturbance factors and the species' response to them largely determines the species composition. Variation in species compositions was found mainly between regions, therefore regionally focused studies are needed to gain a better understanding about local factors. This study provides a basis for further planning of more analytical studies of field boundary plant communities, and animals dependent on the vegetation.

Kleijn et al. (2001) made evident the insuffi- ciency of current agri-environment schemes to protect biodiversity in the Netherlands, where agriculture is extremely intensive comparing to Finland. Nevertheless, we found species poor boundaries especially in southern areas, which may need additional management as mowing with biomass removal or cattle grazing to improve species diversity. However, these practises are difficult to carry out in boundaries usually not more than three meters wide.

Acknowledgements. We are grateful to Virpi Aalto, Erkki Alho, Mira Heiskanen, Teppo Häyhä, Eija Lintula, Anne Nissinen, Aki Sinkkonen and Pekka Ylhäinen, who collected the data in the field. We also want to thank Jan-Peter Bäckman, Maohua Ma, Laura Seppänen, Iryna Herzon, K.V. Sykora and anonymous referees for useful comments on the manuscript. The data were collected in the project 'Monitoring the impacts of Agri-Environmental Support Schemes' (MYTVAS) financed by the Ministry of Agriculture and Forestry. This study was also financed by the Finnish Cultural Foundation and the Agricultural Research Foundation of August Johannes and Aino Tiura. Marcus Walsh kindly checked the English.

\section{References}

Aebischer, N.J., Blake, K.A. \& Boatman, N.D. 1994. Field margins as habitats for game. In: Boatman, N.D. (ed.). Field margins: Integrating agriculture and conservation. BCPC Monograph 58: 95-104.

Alalammi, P. 1987. Suomen kartasto. IImasto. Vihko 131. Maanmittaushallitus, Helsinki. $31 \mathrm{p}$.

Alanen, A. 1997. Maaseudun mansikkapaikat - muistojako vain? Luonnon Tutkija 5: 197-208.

Bäckman, J.P.C. \& Tiainen, J. 2002. Habitat quality of field margins in a Finnish farmland area for bumblebees (Hymenoptera: Bombus and Psithyrus). Agriculture, Ecosystems \& Environment 89: 53-68.

Bayram, A. \& Luff, M.L. 1993. Winter abundance and diversity of lycosids (Lycosidae, Araneae) and other spiders in grass tussocks in a field margin. Pedobiologia 37: 357-364.

Canters, K.J. \& Tamis, W.L.M. 1999. Arthropods in grassy field margins in the Wieringermeer Scope, population development and possible consequences for farm practice. Landscape and Urban Planning 46: 63-69.

Dennis, P. \& Fry, G.L.A. 1992. Field margins: can they enhance natural enemy population densities and general arthropod diversity on farmland. Agriculture, Ecosystems and Environment 40: 95-115.

Dennis, P., Thomas, M.B. \& Sotherton, N.W. 1994. Structural features of field boundaries which influence the overwintering densities of beneficial arthropod predators. Journal of Applied Ecology 31: 361-370.

Dover, J.W., Clarke, S.A. \& Rew, L. 1992. Habitats and movement patterns of satyrid butterflies (Lepidoptera: Satyridae) on arable farmland. Entomologist's Gazette 43: 29-44.

Ellenberg, H., Weber, H.E., Düll, R., Wirth, V., Werner, W. \& Paulißen, D. 1991. Zeigerwerte von Pflanzen in Mitteleuropa. Scripta Geobotanica 18: 1-248.

Foster, B.L. \& Gross, K.L. 1998. Species richness in a successional grassland: effects of nitrogen enrichment and plant litter. Ecology 78: 2593-2602.

Fournier, E. \& Loreau, M. 1999. Effects of newly planted hedges on ground-beetle diversity (Coleoptera, Carabidae) in an agricultural landscape. Ecography 22: 87-97.

Granlund, K., Rekolainen, S., Grönroos, J., Nikander, A. \& Laine, Y. 2000. Estimation of the impact of fertilisation rate on nitrate leaching in Finland using a 
Tarmi, S. et al. Plant communities of field boundaries

mathematical simulation model. Agriculture, Ecosystem and Environment 80: 1-13.

Grönroos, J., Rekolainen, S., Palva, R., Granlund, K., Bärlund, I., Nikander, A. \& Laine, Y. 1998. Maatalouden ympäristötuki. Toimenpiteiden toteutuminen ja vaikutukset v. 1995-1997. Suomen ympäristö 239. 77 p.

Hansson, M. \& Fogelfors, H. 1998. Management of permanent set-aside on arable land in Sweden. Journal of Applied Ecology 35: 758-771.

Hämet-Ahti, L., Suominen, J., Ulvinen, T., Uotila, P. \& Vuokko, S. (eds.). 1986. Retkeilykasvio. Suomen Luonnonsuojelun Tuki, Helsinki. 598 p.

Hietala-Koivu, R. 1999. Agricultural landscape change: a case study in Yläne, southwest Finland. Landscape and Urban Planning 46: 103-108.

Hill, M.O. 1979. DECORANA: a FORTRAN program for detrended correspondence analysis and reciprocal averaging. Section of Ecology and Systematics, Cornell University, Ithaca, New York. 52 p.

Hilli, A. 1949. Piennarkasvustojen maataloudellisesta merkityksestä. Suomen Maataloustieteellisen Seuran julkaisuja $70.62 \mathrm{p}$.

Information Centre of the Ministry of Agriculture and Forestry 1999. Yearbook of Farm Statistics. Agriculture, forestry and fishery 12. Helsinki: Hakapaino Oy. $262 \mathrm{p}$.

Jongman, R.H.G., ter Braak, C.J.F. \& van Tongeren, O.F.R. 1995. Data analysis in community and landscape ecology. 2nd ed. Cambridge University Press. $299 \mathrm{p}$.

Kleijn, D. 1996. The use of nutrient resources from arable fields by plants in field boundaries. Journal of Applied Ecology 33: 1433-1440

Kleijn, D. 1997. Species richness and weed abundance in the vegetation of arable field boundaries. PhD thesis. Wageningen Agricultural University, Wageningen. $177 \mathrm{p}$.

Kleijn, D., Berendse, F., Smit, R. \& Gilissen, N. 2001. Agri-environment schemes do not effectively protect biodiversity in Dutch agricultural landscapes. Nature 413: 723-725.

Kleijn, D., Joenje, W., Le Coeur, D. \& Marshall, E.J.P. 1998. Similarities in vegetation development of newly established herbaceous strips along contrasting European field boundaries. Agriculture, Ecosystems and Environment 68: 13-26.

Kleijn, D. \& Snoeijing, I.J. 1997. Field boundary vegetation and the effects of agrochemical drift: botanical change caused by low levels of herbicide and fertilizer. Journal of Applied Ecology 34: 1413-1425.

Kleijn, D. \& Verbeek, M. 2000. Factors affecting the species compostition of arable field boundary vegetation. Journal of Applied Ecology 37: 256-266.

Kuussaari, M., Heliölä, J., Salminen, J. \& Niininen, I. 2001. Maatalousympäristön päiväperhosseurannan vuoden 2000 tulokset. (Results of the butterfly monitoring scheme in Finnish agricultural landscapes for the year 2000). Babtria 26: 69-79.

Lagerlöf, J., Stark, J. \& Svensson, B. 1992. Margins of agricultural fields as habitats for pollinating insects. Agriculture, Ecosystems and Environment 40: 117124.
Le Coeur, D., Baudry, J. \& Burel, F. 1997. Field margins plant assemblages: variation partitioning between local and landscape factors. Landscape and Urban Planning 37: 57-71.

Ma, M., Tarmi, S. \& Helenius, J. 2002. Revisited species-area relationship in a semi-natural habitat: floral richness in agricultural buffer zones. Agriculture, Ecosystems \& Environment 89: 137-148.

Marrs, R.H., Gough, M.W. \& Griffiths, M. 1991. Soil chemistry and leaching losses of nutrients from semi-natural grassland and arable soils on three contrasting parent materials. Biological Conservation 57: 257271.

Marshall, E.J.P. 1989. Distribution patterns of plants associated with arable field edges. Journal of Applied Ecology 26: 247-257.

Marshall, E.J.P. 1990. Interference between sown grasses and the growth of rhizome of Elymus repens (couch grass). Agriculture, Ecosystems and Environment 33: 11-22.

Marshall, E.J.P. \& Arnold, G.M. 1995. Factors affecting field weed and field margin flora on a farm in Essex, UK. Landscape and Urban Planning 31: 205-216.

Ministry of Agriculture and Forestry 2000. Ympäristötukiopas. $28 \mathrm{p}$.

Oksanen, J. 1981. Reindeer lichen (Cladina) vegetation of rock outcrops on a coast - inland transect in South Finland. Annales Botanici Fennici 18: 133-154.

Pfiffner, L. \& Luka, H. 2000. Overwintering of arthropods in soils of arable fields and adjacent semi-natural habitats. Agriculture, Ecosystems and Environment 78: 215-22

Raatikainen, M. 1991. Rikkakasvikuvasto. Kasvinsuojeluseuran julkaisuja 82. Kasvinsuojeluseura ry. $136 \mathrm{p}$.

Ruuska, R. \& Helenius, J. 1996. GIS analysis of change in an agricultural landscape in Central Finland. Agricultural and Food Science in Finland 5:567-576.

Saarinen, K., Marttila, O. \& Jantunen, J. 1998. Species richness and distribution of butterflies (Lepidoptera: Hesperioidea, Papilionoidea) in an agricultural environment in SE Finland. Entomologica Fennica 9: 918.

Siemann, E. 1998. Experimental tests of effects of plant productivity and diversity on grassland arthropod diversity. Ecology 79: 2057-2070

Silfverberg, H. 1996. Niittyjemme eläimiä värikuvina. 3rd ed. Porvoo: WSOY. $177 \mathrm{p}$.

Sparks, T.H. \& Parish, T. 1995. Factors affecting the abundance of butterflies in field boundaries in swavesey fens, Cambridgeshire, UK. Biological conservation 73: 221-227.

SPSS TM Inc 1997. SYSTAT for Windows Version 7.

ter Braak, C.J.F. 1987. CANOCO - a FORTRAN program for canonical community ordination by partial detrended canonical correspondence analysis, principal components analysis and redundancy analysis (version 2.1). Agricultural Mathematics Group, Wageningen. $95 \mathrm{p}$.

Tiainen, J. \& Pakkala, T. 2000. Maatalousympäristön linnuston muutokset ja seuranta Suomessa. In: Linnut -vuosikirja. p. 98-105. 
Vol. 11 (2002): 121-135.

Tilman, D., Wedin, D. \& Knops, J. 1996. Productivity and sustainability influenced by biodiversity in grassland ecosystems. Nature 379: 718-720.

Väisänen, R.A. 1999. Jyrkimmin taantuneet yleiset maalinnut. Linnut 34: 6-8.

Wilson, J.D., Morris, A.J., Arroyo, B.E., Clark, S.C. \& Bradbury, R.B. 1999. A review of the abundance and diversity of invertebrate and plant foods of granivorous birds in northern Europe in relation to agricultural change. Agriculture, Ecosystems and Environment 75: $13-30$.

Wilson, P.J. \& Aebischer, N.J. 1995. The distribution of dicotyledonous arable weeds in relation to distance from the field edge. Journal of Applied Ecology 32: 295-310.

\title{
SELOSTUS
}

\section{Pellon pientareiden kasviyhteisöt Suomessa}

\author{
Sanna Tarmi, Hannu Tuuri ja Juha Helenius \\ Helsingin yliopisto ja MTT (Maa- ja elintarviketalouden tutkimuskeskus)
}

Pientareiden kasviyhteisöjen lajiston selvittämiseksi tutkimme kaikkiaan 193 piennarta, jotka sijaitsivat tuotantosuunniltaan ja ilmastoltaan erilaisilla alueilla Suomessa. Pientareet ryhmiteltiin kasvillisuutensa perusteella kuuteen kasvillisuustyyppiin.

Pientareiden kasvilajit olivat enimmäkseen tuoreilta tai sitä kosteammilta kasvupaikoilta. Lisäksi kasvit olivat typen suosijoita, jotka viihtyvät parhaiten kohtalaisesti tai sitä runsaammin mineraalityppeä sisältävillä kasvupaikoilla. Yleisimmät lajit olivat korkeakasvuisia, monivuotisia yksi- ja kaksisirkkaisia, jotka tuottavat biomassaa runsaasti. Myös rikkakasvien torjunta-aineita sietävät lajit olivat yleisiä. Suomessa harvinaisia kasvilajeja ei pientareilta havaittu. Tuotantomuotojen alueelliset erot näkyivät kasviyhteisöissä. Karjatalousvaltaisilla alueilla yleisimmät lajit olivat kylvettäviä nurmilajeja ja nurmien rikkakasveja. Viljanviljelyalueilla herbisidejä sietävät ja nopeasti leviävät juuririkkakasvit olivat ylei- simpiä. Lajimäärä oli suurin Calamagrostis-Phalaris tyypissä (24 lajia /piennar), jonka tulkitsimme olevan kostea ja luonnontilainen kasvupaikka. Pienimmät lajimäärät olivat Elymus-Anthriscus (14 lajia/ piennar) ja Elymus-Cirsium tyypeillä, joita löytyi eniten viljanviljelyyn keskittyneiltä eteläisiltä alueilta.

Tulosten perusteella viljelytoimilla on suuri merkitys pientareiden kasviyhteisöjen lajikoostumukseen. Nurmen kuuluminen viljelykiertoon, muokkauksen tehokkuus ja rikkakasvien torjunta-aineiden käyttö ovat ilmeisesti tärkeitä kasvillisuuteen vaikuttavia tekijöitä. Aiemman maatalouspolitiikan seurauksena viljanviljely on keskittynyt eteläisille ja karjatalous taas pohjoisemmille maatalousalueille, mikä on epäsuorasti vaikuttanut alueelliseen piennarkasvillisuuteen. Jatkotutkimuksissa on tarpeen selvittää, miten pientareet eroavat alueiden sisällä toisistaan ja mitkä paikalliset tekijät eroja aiheuttavat. 
Appendix 1. List of species found in boundaries.

\begin{tabular}{|c|c|c|c|c|c|}
\hline & Abbreviation & Species & & Abbreviation & Species \\
\hline I & ACH MIL & Achillea millefolium $\mathrm{L}$. & $\mathrm{O}$ & & Leucanthemum vulgare Lam. \\
\hline I & ACH PTA & A. ptarmica $\mathrm{L}$. & I & & Linaria vulgaris Mill. \\
\hline I & AEG POD & Aegopodium podagraria $\mathrm{L}$. & $\mathrm{I}$ & & Lolium perenne $\mathrm{L}$. \\
\hline I & & Agrostis capillaris L. & $\mathrm{O}$ & & Luzula pallescens Swartz \\
\hline $\mathrm{O}$ & & A. gigantea Roth & $\mathrm{O}$ & & L. sudetica (Willd.) DC. \\
\hline $\mathrm{O}$ & & A. stolonifera & I & LEO AUT & Leontodon autumnalis L. \\
\hline I & AGR SP & Agrostis sp. L. & I & LYS SP & Lysimachia sp. L. \\
\hline I & ALC SP & Alchemilla sp. L. & $\mathrm{O}$ & & Maianthemum bifolium (L.) F.W. Schmidt \\
\hline I & & Alopecurus geniculatus L. & $\mathrm{I}$ & MAT MAT & Matricaria matricarioides (Less.) Porter \\
\hline I & ALO PRA & A. pratensis L. & I & & Mentha arvensis $\mathrm{L}$. \\
\hline I & ANG SYL & Angelica sylvestris $\mathrm{L}$. & I & MYO ARV & Myosotis arvensis (L.) Hill \\
\hline $\mathrm{O}$ & & Anthoxanthum odoratum L. & $\mathrm{O}$ & & Nardus stricta $\mathrm{L}$. \\
\hline I & ANT SYL & Anthriscus sylvestris (L.) Hoffm. & $\mathrm{O}$ & & Odontites vulgaris Moench \\
\hline $\mathrm{O}$ & & Arctium tomentosum Miller & $\mathrm{I}$ & & Peucedanum palustre (L.) Moench \\
\hline I & ART VUL & Artemisia vulgaris $\mathrm{L}$. & $\mathrm{I}$ & PHA ARU & Phalaris arundinacea $\mathrm{L}$. \\
\hline $\mathrm{O}$ & & Atriplex patula $\mathrm{L}$. & I & PHL PRA & Phleum pratense L. \\
\hline $\mathrm{I}$ & & Barbarea vulgaris $\mathrm{R} . \mathrm{Br}$. & I & & $\begin{array}{l}\text { Phragmites australis (Cav.) Trin. ex } \\
\text { Steud. }\end{array}$ \\
\hline $\mathrm{I}$ & & Betula sp. L. & $\mathrm{O}$ & & Pimpinella saxifraga $\mathrm{L}$. \\
\hline I & & Bidens tripartita $\mathrm{L}$. & $\mathrm{I}$ & PLA MAJ & Plantago major $\mathrm{L}$. \\
\hline I & CAL SP & Calamagrostis sp. Adans. & I & POA SP & Poa sp. L. \\
\hline I & & C. rotundifolia $\mathrm{L}$. & I & POL AMP & Polygonum amphibium $\mathrm{L}$. \\
\hline $\mathrm{O}$ & & Caltha palustris $\mathrm{L}$. & $\mathrm{I}$ & POL AVI & P. aviculare L. \\
\hline $\mathrm{O}$ & & Campanula glomerata $\mathrm{L}$. & $\mathrm{I}$ & & P. hydropiper L. \\
\hline $\mathrm{O}$ & & C. patula $\mathrm{L}$. & I & POL LAP & P. lapathifolium $\mathrm{L}$. \\
\hline I & & Capsella bursa-pastoris (L.) Medik. & I & & Potentilla anserina $\mathrm{L}$. \\
\hline $\mathrm{I}$ & CAR SP & Carex sp. L. & $\mathrm{O}$ & & P. erecta \\
\hline I & & Cerastium arvense $\mathrm{L}$. & I & & $P$. norvegica $\mathrm{L}$. \\
\hline I & CER FON & C. fontanum Baumg. & $\mathrm{I}$ & RAN ACR & Ranunculus acris L. \\
\hline I & CHE ALB & Chenopodium album $\mathrm{L}$. & I & RAN REP & $R$. repens $\mathrm{L}$. \\
\hline I & & C. suecicum Murr & $\mathrm{O}$ & & Rhinanthus serotinus (Schönh.) Oborny \\
\hline $\mathrm{O}$ & & Cicuta virosa $\mathrm{L}$. & $\mathrm{I}$ & & Rorippa palustris (L.) Besser \\
\hline $\mathrm{I}$ & CIR ARV & Cirsium arvense Mill. & $\mathrm{O}$ & & Rosa majalis J. Herrmann \\
\hline I & CIR HEL & C. helenioides (L.) Hill & I & & Rosa sp. L. \\
\hline $\mathrm{O}$ & & Convallaria majalis $\mathrm{L}$. & $\mathrm{I}$ & RUB ARC & Rubus arcticus $\mathrm{L}$. \\
\hline $\mathrm{I}$ & & Cuscuta europaea $\mathrm{L}$. & $\mathrm{I}$ & RUB IDA & R. idaeus L. \\
\hline I & & Dactylis glomerata $\mathrm{L}$. & I & RUM ACE & Rumex acetosa $\mathrm{L}$. \\
\hline I & DES CES & Deschampsia cespitosa (L.) P.Beauv. & $\mathrm{I}$ & & R. acetosella $\mathrm{L}$. \\
\hline $\mathrm{O}$ & & $\begin{array}{l}\text { Eleocharis mamillata (H. lindb.) H. } \\
\text { Lind. ex Dörfler }\end{array}$ & I & & R. longifolius DC. \\
\hline I & & Elymus caninus (L.) L. & $\mathrm{O}$ & & Sagina procumbens L. \\
\hline $\mathrm{I}$ & ELY REP & E. repens (L.) Gould & $\mathrm{I}$ & & Salix sp. L. \\
\hline I & & Epilobium adenocaulon Hausskn. & $\mathrm{I}$ & & Scirpus sylvaticus L. \\
\hline $\mathrm{I}$ & EPI ANG & E. angustifolium $\mathrm{L}$. & $\mathrm{O}$ & & Scleranthus annuиs L. \\
\hline $\mathrm{I}$ & & E. palustre $\mathrm{L}$. & $\mathrm{O}$ & & Scrophularia nodosa L. \\
\hline I & EQU ARV & Equisetum arvense $\mathrm{L}$. & $\mathrm{O}$ & & Solidago virgaurea $\mathrm{L}$. \\
\hline I & & E. fluviatile $\mathrm{L}$. & $\mathrm{I}$ & SON ARV & Sonchus arvensis L. \\
\hline I & & E. palustre $\mathrm{L}$. & $\mathrm{I}$ & & S. asper (L.) Hill \\
\hline I & & E. sylvaticum $\mathrm{L}$. & $\mathrm{I}$ & SPE ARV & Spergula arvensis $\mathrm{L}$. \\
\hline $\mathrm{O}$ & & Eriophorum angustifolium Honckeny & $\mathrm{O}$ & & Stachys palustris L. \\
\hline $\mathrm{I}$ & ERY CHE & Erysimum cheiranthoides L. & $\mathrm{I}$ & STE GRA & Stellaria graminea $\mathrm{L}$. \\
\hline I & & Euphorbia helioscopia L. & I & STE MED & S. media (L.) Vill. \\
\hline
\end{tabular}


Appendix 1. List of species found in boundaries.

\begin{tabular}{|c|c|c|c|c|c|}
\hline & Abbreviation & Species & & Abbreviation & Species \\
\hline I & & $\begin{array}{l}\text { Euphrasia stricta D. Wolff ex } \\
\text { J.F.Lehm. }\end{array}$ & $\mathrm{O}$ & & Succisa pratensis Moench \\
\hline I & & Fallopia convolvulus (L.) Á. Löve & I & & Tanacetum vulgare $\mathrm{L}$. \\
\hline I & FES SP & Festuca sp.L. & I & TAR SP & Taraxacum sp. Weber \\
\hline I & FIL ULM & Filipendula ulmaria (L.) Maxim. & I & & Thalictrum flavum $\mathrm{L}$. \\
\hline I & & Fumaria officinalis L. & $\mathrm{O}$ & & Thelypteris phegopteris (L.) Slosson \\
\hline I & GAL SP & Galeopsis sp. L. & $\mathrm{O}$ & & Thlaspi arvense $\mathrm{L}$. \\
\hline I & GAL ALB & Galium album Mill. & I & & Trifolium hybridum $\mathrm{L}$. \\
\hline I & GAL BOR & G. boreale L. & I & TRI MED & T. medium $\mathrm{L}$. \\
\hline I & & G. palustre $\mathrm{L}$. & I & TRI PRA & T. pratense $\mathrm{L}$. \\
\hline I & GAL SPU & G. spurium $\mathrm{L}$. & I & TRI REP & T. repens $\mathrm{L}$. \\
\hline I & GAL ULI & G. uliginosum $\mathrm{L}$. & I & TRI INO & Tripleurospermum inodorum Sch. Bip. \\
\hline $\mathrm{O}$ & & Geranium sylvaticum $\mathrm{L}$. & I & TUS FAR & Tussilago farfara $\mathrm{L}$. \\
\hline $\mathrm{O}$ & & Glechoma hederacea $\mathrm{L}$. & I & URT DIO & Urtica dioica $\mathrm{L}$. \\
\hline $\mathrm{O}$ & & Glyceria fluitans (L.) R. Br. & $\mathrm{O}$ & & U. urens $\mathrm{L}$. \\
\hline I & GNA ULI & Gnaphalium uliginosum $\mathrm{L}$. & $\mathrm{O}$ & & Vaccinium myrtillus $\mathrm{L}$. \\
\hline I & & Hierochloë hirta (Schrank) Borbás & I & VAL SAM & Valeriana sambucifolia J.C. Mikan \\
\hline I & & Hypericum maculatum Crantz & $\mathrm{O}$ & & Valeriana sp. \\
\hline I & & Juncus bufonius L. & I & & Veronica chamaedrys L. \\
\hline $\mathrm{O}$ & & J. effusus L. & I & & V. officinalis $\mathrm{L}$. \\
\hline I & & J. filiformis L. & $\mathrm{O}$ & & V. serpyllifolia $\mathrm{L}$. \\
\hline I & LAC SIB & Lactuca sibirica (L.) Maxim. & $\mathrm{O}$ & & V. spicata $\mathrm{L}$. \\
\hline I & & Lamium hybridum Vill. & $\mathrm{O}$ & & Veronica sp. L. \\
\hline $\mathrm{O}$ & & Lamium sp. L. & I & VIC CRA & Vicia cracca $\mathrm{L}$. \\
\hline I & & L. purpureum $\mathrm{L}$. & I & VIC SEP & V. sepium L. \\
\hline I & LAP COM & Lapsana communis L. & I & VIO ARV & Viola arvensis Murray \\
\hline I & LAT PRA & Lathyrus pratensis $\mathrm{L}$. & $\mathrm{O}$ & & V. canina \\
\hline $\mathrm{O}$ & & Lemna minor $\mathrm{L}$. & I & VIO PAL & V. palustris $\mathrm{L}$. \\
\hline
\end{tabular}

Species marked with (I) were included in and species marked with $(\mathrm{O})$ were omitted or made passive in correspondence analysis. The 60 most frequent species (with abbreviations) are plotted in Fig. 3. 